Asian J. Med. Biol. Res. 2021, 7 (1), 33-39; doi: 10.3329/ajmbr.v7i1.53306

\author{
Asian Journal of \\ Medical and Biological Research \\ ISSN 2411-4472 (Print) 2412-5571 (Online) \\ www.ebupress.com/journal/ajmbr
}

\title{
Article \\ Performance of different commercial layer strains in Bangladesh
}

\author{
Md. Kamrul Hasan ${ }^{1 *}$, Md. Anisur Rahman ${ }^{1}$, Hasnat Mamun ${ }^{1}$, Md. Nazmul Hossain ${ }^{2}$ and Md. Mukthar Mia ${ }^{1}$ \\ ${ }^{1}$ Department of Poultry Science, Faculty of Veterinary, Animal and Biomedical Sciences, Sylhet Agricultural \\ University, Bangladesh \\ ${ }^{2}$ Department of Livestock Production and Management, Faculty of Veterinary, Animal and Biomedical \\ Sciences, Sylhet Agricultural University, Bangladesh
}

*Corresponding author: Md. Kamrul Hasan, Department of Poultry Science, Faculty of Veterinary, Animal and Biomedical Sciences, Sylhet Agricultural University, Bangladesh. Phone: +8801627493383; E-mail: kamrul.ps@sau.ac.bd

Received: 24 February 2021/Accepted: 18 March 2021/ Published: 31 March 2021

\begin{abstract}
To know the production performances of different commercial layer strains in Bangladesh, total 18,420 birds of ISA Brown, 14,790 birds of Novogen-Brown and 27,400 birds of Shavar-579 Brown were studied from 30 commercial layer farms (10 farms for each strain), which were randomly selected from the 7 different districts of Bangladesh by farm visit via a well structured questionnaire. All birds were reared in opensided shed in cage system. The hen day egg production percentage (HDEP\%), average body weight and average feed intake per day of three different strains were studied. The HDEP\% of ISA Brown, Novogen-Brown and Shaver-579 Brown were $90.79 \pm 0.44 \%, 78.89 \pm 1.84 \%$ and $79.13 \pm 1.41 \%$ respectively, average body weight were $1877 \pm 26.4 \mathrm{gm}, 1885 \pm 26.9 \mathrm{gm}$ and $1815.5 \pm 43.9 \mathrm{gm}$ respectively, average feed intake per day were $111 \pm 1.88$ $\mathrm{gm}, 109.8 \pm 1.86 \mathrm{gm}$ and $112.5 \pm 1.35 \mathrm{gm}$ respectively. The HDEP\% was higher in ISA Brown, however there were no significant difference among strains for average body weight and average feed intake per day. Finally, it is recommended that ISA Brown is more adaptable and profitable in Bangladesh than that of other strains. Further scientific study is needed to see the production performance of different commercial layer strains in farm trail with same environmental condition.
\end{abstract}

Keywords: layer strains; HDEP; feed intake; body weight

\section{Introduction}

Poultry sector play an important role to reduce malnutrition of the people of Bangladesh by supplying quality meat and egg. It also plays a vital role to increase the agricultural growth of Bangladesh. Different types of stakeholder are related in this poultry sector such as farmer, feed companies, veterinarian, animal scientist, poultry equipment supplier and pharmaceutical companies. In our poultry sector, over 1 million entrepreneurs and 8 million people are directly involved (Hamid et al., 2017). The contribution of livestock sub-sector in our GDP (Gross Domestic Products) is 3.47\% in FY 2018-19 (DLS, 2018). Despite of huge production of eggs, our small-scale layer farmers are not getting profit nowadays. Selection of breed and strain, environmental condition of the house, management practices like feed and feeding management, climatic condition and biosecurity are the major factors which have a direct influence on the production of quality egg (Talukder et al., 2010). Due to genetic variation there are differences in production performance among different breeds and strains.

Layer strains are produced by breeding companies on the basis of selection of different desirable traits- age of sexual maturity, egg production per hen, age of peak egg production, rate of laying before and after moult, livability and blood and meat spot eggs. Among different desirable traits egg production per hen is the top most important trait for the selection of layer strains for commercial layer farms (Bennewitz et al., 2007). Egg production and quality differ among strains because of genetic variation (Moreng \& Avens, 1985; Harms et al., 
2000). More than 10 commercial layer strains are available at field level in Bangladesh and most common commercial layer strains are ISA Brown, Hy-line White, Hy-line Brown, Shavar-579 Brown, Novogen-Brown, Hy-sex White and Hy-sex Brown. Among them some are white shell egg producer (Hy-line White, Hy-sex White) and some are brown shell egg producer (ISA Brown, Hy-line Brown, Shavar-579 Brown, NovogenBrown and Hy-sex Brown). Generally, brown egg producing strains exhibit early sexual maturity (132.07 days) than the white egg producing strains (137.8 days). Moreover, hen day egg production (HDEP) of brown egg producing strains is higher $(85.6 \%)$ than the white egg producing strains (83.2\%) (Anderson et al., 2004). For this reason our farmers prefer to rear brown egg producing strains than the white egg producing strains. To get optimum growth and higher egg production from different commercial layer stains a better layer management is needed (Samad, 2013).

Quality egg production is the key of success for commercial layer business, because a layer farmer gets $90 \%$ of total farm income from selling of eggs (Oluyemi and Robert, 1979). Generally, layer birds reach in sexual maturity at 19 weeks of age, and the goes to the peak egg production between 26 to 30 weeks of age and farmers replace their birds between 72 to 76 weeks of age when it gives less than $60 \%$ of egg production (Rahman, 2003). To meet up our egg requirement and for profitable layer farming we need optimum level of egg production through high yielding strains. From this study, we wanted to know the production performance of different commercial layer strains in Bangladesh to find out the more suitable and profitable commercial layer strain for farmers.

\section{Materials and Methods}

\subsection{Study area, time and data collection}

Different commercial layer farms were randomly selected from 7 different districts of Bangladesh (Kishoreganj, Narsingdi, Rajshahi, Gazipur, Chattogram, Sylhet and Sunamganj) over a period of 6 months (September to February, 2020). The addresses of farmers were collected with the help of veterinary surgeons of different districts and upazila's. On the basis of availability of different commercial layer strains, farms of ISA Brown, Novogen-Brown and Shaver-579 Brown were selected and total 30 commercial layer farms (10 farms for each strain) were visited and interview of farmers were taken with a structured questionnaire. Birds of all commercial layer farms were reared in open-sided shed in cage system. Total number of layer birds was 60,610 in 30 commercial layer farms. There were 18,420 number of birds of ISA Brown strain in 10 farms, 14,790 number of birds of Novogen-Brown strain in 10 farms and 27,400 number of birds of Shavar-579 Brown strain in 10 farms.

\subsection{Data entry and data management}

The raw data were entered in a spread sheet with the help of Microsoft Office Excel 2016. The different information putted into the spread sheet was as follows- name of strain, number of birds in the farm, rearing system, age of the birds (weeks), average body weight of the birds (gm), standard body weight as per strain (gm), average feed intake by per bird per day (gm), standard feed intake by per bird per day (gm) as per strain, number of eggs produced per day, HDEP\% (Hen Day Egg production) and standard egg production \% as per strain.

\subsection{Measurement of Hen Day Egg production}

Hen Day Egg production percentage of the farm were measured by following index:

$$
\mathrm{HDEP} \%=\frac{\text { Total number of eggs produced on a day }}{\text { Total number of hens present on that day }} \times 100
$$

\subsection{Statistical procedure}

Different parameters (Hen day egg production percentage (HDEP\%), average body weight and average feed intake per bird) were analyzed by ANOVA using the GLM procedure of Minitab statistical software (2019) at $5 \%$ level of significance. Tukey pairwise comparisons were used to see the variation among different strains for HDEP\%.

\section{Results and Discussion}

The production performances of ISA Brown strain between 25 to 70 weeks of bird's age are shown in Table 1 . The average HDEP\% (Hen Day Egg Production) for ISA Brown strain was $90.79 \%$ for 25 to 70 weeks of age. Among the farms of ISA Brown strain, highest $92.5 \%$ HDEP were recorded at 37 weeks of age and lowest $88.75 \%$ HDEP were recorded at 41 weeks of age. 
The average body weight and average feed intake per day for ISA Brown strain were recorded $1877.77 \mathrm{gm}$ and $111 \mathrm{gm}$ respectively between the age ranges from 25 to 70 weeks. According to the standard of ISA Brown strain, the average body weight, feed intake per day and HDEP\% are $1941.36 \mathrm{gm}, 112.90 \mathrm{gm}$ and 91.87\%, respectively between 25 to 70 weeks of age (ISA Brown Commercial Product Guide, 2019). The standard data of body weight, feed intake per day and HDEP\% of ISA Brown strain between 25 to 70 weeks of age are presented in Table 2. In comparison with data recorded in this study, the average body weight (1877.77 gm), average feed intake per day (111 gm) and average HDEP\% (90.79) between 25 to 70 weeks of age, all are lower than the standard of ISA Brown strain.

The production performances of Novogen-Brown strain are shown in Table 3. The average HDEP\% for Novogen-Brown strain was $78.89 \%$ for 26 to 65 weeks of age. Highest $83.8 \%$ HDEP were recorded at 49 weeks of age and lowest $70.51 \%$ HDEP were recorded at 64 weeks of age for Novogen-Brown strain. In the farm, the average body weight and average feed intake per day between 26 to 65 weeks of age for Novogen-Brown strain were recorded $1885 \mathrm{gm}$ and $109.8 \mathrm{gm}$ respectively. According to the standard of Novogen-Brown strain, the average body weight, feed intake per day and HDEP\% are $1861.11 \mathrm{gm}, 115 \mathrm{gm}$ and $88.66 \%$, respectively between the ages of 26 to 65 weeks (Commercial Layers Management Guide - Novogen-Brown, 2018). The standard body weight, feed intake per day and HDEP\% for Novogen-Brown strain between 26 to 65 weeks of age are shown in Table 4. In comparison with data recorded from farms in this study, the average body weight (1885 gm) is higher than the standard of Novogen-Brown strain, the average feed intake per day (109.8 gm) and average HDEP\% (78.89\%) are lower than the standard of Novogen-Brown strain.

The average HDEP\% for Shaver-579 Brown strain was recorded $79.13 \%$ between 22 to 67 weeks of age. For Shaver-579 Brown strain, highest $83.78 \%$ HDEP was recorded at 40 weeks of age and lowest $70 \%$ HDEP recorded at 67 weeks of age. The production performances of Shaver-579 Brown strain between 22 to 67 weeks of age are shown in Table 5. The average body weight and average feed intake per day for Shaver-579 Brown strain was recorded $1815.5 \mathrm{gm}$ and $112.5 \mathrm{gm}$ respectively between the age of 22 and 67 weeks. According to the standard of Shaver-579 Brown strain, the average body weight, feed intake per day and HDEP\% are $1838 \mathrm{gm}$, 111.75 gm and $89.61 \%$, respectively within the age of 22 and 67 weeks (Shaver Brown product guide cage production system, 2019). The standard body weight, feed intake per day and HDEP\% of Shavar-579 Brown strain between 22 to 67 weeks of age are presented in Table 6. In comparison with data recorded from different farms, the average body weight (1815.5 gm), and average HDEP\% (79.13) are lower than the standard of Shaver-579 Brown strain, however average feed intake per day per bird (112.5 gm) is higher than the standard of Shaver-579 Brown strain between 22 to 67 weeks of age.

Among the 3 strains the highest HDEP\% were recorded (90.79\%) for ISA Brown strain followed by Shaver-579 Brown $(79.13 \%)$ and Novogen-Brown $(78.89 \%)$. The hen day egg production (HDEP\%), average body weight and average feed intake per day of different strains are shown in Table 7. The values obtained in this study for HDEP\% for ISA Brown layer strain is higher than the findings of Renema et al., (2001) (86.7\% HDEP for ISA Brown strain), Okedere et al., (2020) (73.79\% HDEP for ISA Brown strain) and Kabir and Haque (2010) (77.11\% HDEP for ISA Brown). However in case of HDEP\% of Shaver-579 Brown layer strain our findings is lower than the Islam et al., (2015) (83.88\% HDEP for Shaver-579 Brown strain). In our study we observed better biosecurity, feeding and lighting management in the farms of ISA Brown layer strain and for this reason ISA Brown layer strain exhibited higher HDEP\% than other strains. The HDEP\% of Novogen-Brown strain is similar with the findings of Cornwall-Thomas (2019) (HDEP\% for Novogen-Brown ranged from 57.7 to 79.1\%). The salient criteria for appraising the performance of the commercial layer strains have been HDEP\% and egg weights. In this study all the findings were not same with recommended level. This occured due to differences in environmental condition, management system, housing system, lighting system, feeding, medication, biosecurity and genetic variation of strain. 
Table 1. Production performances of ISA Brown strain in farms.

\begin{tabular}{|c|c|c|c|c|c|c|}
\hline $\begin{array}{l}\text { Farm } \\
\text { No. }\end{array}$ & $\begin{array}{l}\text { Birds age } \\
\text { (Wks) }\end{array}$ & $\begin{array}{l}\text { No. of } \\
\text { Birds }\end{array}$ & $\begin{array}{l}\text { Av. body } \\
\text { weight/bird (gm) }\end{array}$ & $\begin{array}{l}\text { Av. feed } \\
\text { intake/bird/day (gm) }\end{array}$ & $\begin{array}{l}\text { No of } \\
\text { Egg/day }\end{array}$ & $\begin{array}{l}\text { HDEP* } \\
\%\end{array}$ \\
\hline Farm 1 & 41 & 4000 & 1900 & 108 & 3550 & 88.75 \\
\hline Farm 2 & 49 & 1490 & 1900 & 117 & 1370 & 91.94 \\
\hline Farm 3 & 47 & 1100 & 1950 & 120 & 998 & 90.72 \\
\hline Farm 4 & 25 & 900 & 1900 & 110 & 804 & 89.33 \\
\hline Farm 5 & 70 & 900 & 1900 & 115 & 817 & 90.77 \\
\hline Farm 6 & 37 & 2000 & 1900 & 105 & 1850 & 92.5 \\
\hline Farm 7 & 57 & 1800 & 1650 & 100 & 1603 & 89.05 \\
\hline Farm 8 & 53 & 2700 & 1900 & 110 & 2444 & 90.5 \\
\hline Farm 9 & 45 & 2750 & 1920 & 115 & 2530 & 92 \\
\hline Farm 10 & 39 & 780 & 1850 & 110 & 720 & 92.3 \\
\hline Mean \pm SEM & & & $1877 \pm 26.4$ & $111 \pm 1.88$ & & $90.79 \pm 0.44$ \\
\hline
\end{tabular}

*HDEP-Hen Day Egg Production

Table 2. Standard body weight, feed intake and HDEP\% of ISA Brown strain.

\begin{tabular}{llll}
\hline $\begin{array}{l}\text { Birds age } \\
\text { (Wks) }\end{array}$ & $\begin{array}{l}\text { Standard body } \\
\text { weight/bird }(\mathbf{g m})\end{array}$ & $\begin{array}{l}\text { Standard feed } \\
\text { intake/bird/day }(\mathbf{g m})\end{array}$ & Standard HDEP\% \\
\hline 25 & 1796 & 112 & 96.1 \\
37 & 1896 & 113 & 95.2 \\
39 & 1906 & 113 & 94.8 \\
41 & 1915 & 113 & 94.4 \\
45 & 1931 & 113 & 93.5 \\
47 & 1939 & 113 & 92.9 \\
49 & 1946 & 113 & 92.3 \\
53 & 1969 & 113 & 90.9 \\
57 & 1969 & 113 & 89.4 \\
70 & 1988 & 113 & 83.5 \\
\hline Mean \pm SEM & $1941.36 \pm 9.14$ & $112.90 \pm 0.09$ & $91.87 \pm 1.05$ \\
\hline
\end{tabular}

*HDEP-Hen Day Egg Production

Source: ISA Brown Commercial Product Guide (2019)

Table 3. Production performance of Novogen-Brown strain in the farm.

\begin{tabular}{|c|c|c|c|c|c|c|}
\hline $\begin{array}{l}\text { Farm } \\
\text { No. }\end{array}$ & Age (Wks) & $\begin{array}{l}\text { No. of } \\
\text { Birds }\end{array}$ & $\begin{array}{l}\text { Average body } \\
\text { weight/bird (gm) }\end{array}$ & $\begin{array}{l}\text { Average feed } \\
\text { intake/bird/day (gm) }\end{array}$ & $\begin{array}{l}\text { No of } \\
\text { Egg/day }\end{array}$ & $\begin{array}{l}\text { HDEP* } \\
\%\end{array}$ \\
\hline Farm 1 & 49 & 1050 & 1900 & 110 & 880 & 83.80 \\
\hline Farm 2 & 40 & 1000 & 1900 & 107 & 800 & 80 \\
\hline Farm 3 & 26 & 400 & 1950 & 110 & 300 & 75 \\
\hline Farm 4 & 64 & 1560 & 1900 & 120 & 1100 & 70.51 \\
\hline Farm 5 & 45 & 2000 & 1900 & 120 & 1650 & 82.5 \\
\hline Farm 6 & 64 & 2600 & 1900 & 110 & 2100 & 80.76 \\
\hline Farm 7 & 65 & 1100 & 1650 & 105 & 790 & 71.81 \\
\hline Farm 8 & 50 & 1000 & 1900 & 105 & 810 & 81 \\
\hline Farm 9 & 60 & 2080 & 1950 & 108 & 1706 & 82.01 \\
\hline Farm 10 & 40 & 2000 & 1900 & 103 & 1630 & 81.5 \\
\hline Mean \pm SEM & & & $1885 \pm 26.9$ & $109.8 \pm 1.86$ & & $78.89 \pm 1.48$ \\
\hline
\end{tabular}

*HDEP-Hen Day Egg Production 
Table 4. Standard body weight, feed intake and HDEP\% of Novogen-Brown strain.

\begin{tabular}{llll}
\hline Age (Wks) & $\begin{array}{l}\text { Standard body } \\
\text { weight/bird (gm) }\end{array}$ & $\begin{array}{l}\text { Standard feed } \\
\text { intake/bird/day (gm) }\end{array}$ & $\begin{array}{l}\text { Standard HDEP* } \\
\mathbf{\%}\end{array}$ \\
\hline 26 & 1790 & 115 & 94 \\
40 & 1840 & 115 & 94 \\
45 & 1850 & 115 & 93 \\
49 & 1860 & 115 & 91 \\
50 & 1860 & 115 & 91 \\
60 & 1880 & 115 & 86 \\
64 & 1890 & 115 & 83 \\
64 & 1890 & 115 & 83 \\
65 & 1890 & 115 & 83 \\
\hline Mean士SEM & $1861.11 \pm 10.94$ & 115 & $88.66 \pm 1.56$ \\
\hline
\end{tabular}

*HDEP-Hen Day Egg Production

Source: Commercial Layers Management Guide - Novogen-Brown (2018)

Table 5. Production performance of Shaver-579 Brown strain in farms.

\begin{tabular}{|c|c|c|c|c|c|c|}
\hline $\begin{array}{l}\text { Farm } \\
\text { No. } \\
\end{array}$ & $\begin{array}{l}\text { Age } \\
\text { (Wks) }\end{array}$ & $\begin{array}{l}\text { No. of } \\
\text { Birds }\end{array}$ & $\begin{array}{l}\begin{array}{l}\text { Average body } \\
\text { weight/bird (gm) }\end{array} \\
\end{array}$ & $\begin{array}{l}\text { Average feed } \\
\text { intake/bird/day (gm) }\end{array}$ & $\begin{array}{l}\text { No of } \\
\text { Egg/day }\end{array}$ & $\begin{array}{l}\text { HDEP* } \\
\%\end{array}$ \\
\hline Farm 1 & 63 & 2000 & 1950 & 110 & 1650 & 82.5 \\
\hline Farm 2 & 40 & 1850 & 1800 & 110 & 1550 & 83.78 \\
\hline Farm 3 & 37 & 5000 & 1825 & 116 & 4100 & 82 \\
\hline Farm 4 & 62 & 6000 & 1950 & 120 & 4560 & 76 \\
\hline Farm 5 & 22 & 1000 & 1650 & 105 & 750 & 75 \\
\hline Farm 6 & 67 & 3000 & 1980 & 115 & 2100 & 70 \\
\hline Farm 7 & 25 & 2500 & 1600 & 114 & 2100 & 84 \\
\hline Farm 8 & 28 & 1050 & 1750 & 110 & 845 & 80.47 \\
\hline Farm 9 & 65 & 3000 & 1950 & 115 & 2340 & 78 \\
\hline Farm 10 & 25 & 2000 & 1700 & 110 & 1590 & 79.5 \\
\hline Mean \pm SEM & & & $1815.5 \pm 43.9$ & $112.5 \pm 1.35$ & & $79.13 \pm 1.41$ \\
\hline
\end{tabular}

*HDEP- Hen Day Egg Production

Table 6. Standard body weight, feed intake and HDEP\% of Shaver-579 Brown strain.

\begin{tabular}{llll}
\hline Age (Wks) & $\begin{array}{l}\text { Standard body } \\
\text { weight/bird as per strain } \\
\text { (gm) }\end{array}$ & $\begin{array}{l}\text { Standard feed } \\
\text { intake/bird/day as per } \\
\text { strain (gm) }\end{array}$ & $\begin{array}{l}\text { Standard HDEP\% as per } \\
\text { Strain }\end{array}$ \\
\hline 22 & 1700 & 111 & 81.3 \\
25 & 1748 & 111 & 95.5 \\
28 & 1748 & 112 & 96.5 \\
37 & 1850 & 112 & 94.3 \\
40 & 1864 & 112 & 93.8 \\
62 & 1929 & 112 & 86.4 \\
63 & 1930 & 112 & 86 \\
67 & 1935 & 112 & 84.1 \\
\hline Mean \pm SEM & $1838 \pm 33.43$ & $111.75 \pm 0.16$ & $89.61 \pm 2.09$ \\
\hline
\end{tabular}

*HDEP- Hen Day Egg Production

Source: Shaver-579 Brown product guide cage production system (2019) 
Table 7. Hen day egg production (HDEP\%), average body weight and average feed intake per day of different strains.

\begin{tabular}{llll}
\hline Parameters (\%/gm) & ISA Brown & Novogen-Brown & Shaver-579 Brown \\
\hline HDEP\% & $90.79 \pm 0.44^{\mathrm{a}}$ & $78.89 \pm 1.48^{\mathrm{b}}$ & $79.13 \pm 1.41^{\mathrm{b}}$ \\
Average body weight $(\mathrm{gm})$ & $1877 \pm 26.4$ & $1885 \pm 26.9$ & $1815.5 \pm 43.9$ \\
Average feed intake per day $(\mathrm{gm})$ & $111 \pm 1.88$ & $109.8 \pm 1.86$ & $112.5 \pm 1.35$ \\
\hline
\end{tabular}

Numbers with a different superscript differ between strains for specific parameter $\mathrm{p} \leq 0.05$, results are shown as means \pm SEM

\section{Conclusions}

In this study, we found higher HDEP\% in ISA Brown than the Novogen-Brown and Shaver-579 Brown. Finally, from the collected data (by farm visit via a well-structured questionnaire) we can say that the ISA Brown layer strain is more adaptable and profitable in Bangladesh than that of other available strains. Further scientific study is needed to see the production performance of different commercial layer strains in farm trail with same environmental condition.

\section{Acknowledgements}

The authors wish to express their sincere and deepest sense of gratitude, heartiest appreciation and profound regards to all commercial layer farmers in the study area for providing permission and other necessary facilities to implement the research work.

\section{Conflict of interest}

None to declare.

\section{References}

Anderson KE, GS Davis, PK Jenkins and AS Carroll, 2004. Effects of bird age, density, and molt on behavioral profiles of two commercial layer strains in cages. Poult. Sci., 83: 15-23.

Bennewitz J, O Morgades, R Preisinger, G Thaller and E Kalm, 2007. Variance component and breeding value estimation for reproductive traits in laying hens using a Bayesian threshold model. Poult. Sci., 86: 823-828.

Cornwall-Thomas A, 2019. The impact of THI on egg production of a layer strain and the implications for climate change. Conference paper.

Directorate of Livestock Services (DLS), 2018. Annual report on livestock, Division of Livestock Statistics, Ministry of Fisheries And Livestock, Farmgate, Dhaka, Bangladesh.

Hamid MA, MA Rahman, S Ahmed and KM Hossain, 2017. Status of poultry industry in Bangladesh and the role of private sector for its development. Asian J. Poult. Sci., 11: 1-3.

Harms RH, GB Russell and DR Sloan, 2000. Performance of four strains of commercial layers with major changes in dietary energy. J. Appl. Poult. Res., 9: 535-541.

ISA Brown Commercial Product Guide, 2019.

Islam S, MS Bari, SP Moni, MZ Siddiqe, MH Uddin and OF Miazi, 2015. Phenotypic Characteristics of Commercial Layer Strains, ISA Brown and Hisex Brown. Int. J. Nat. Sci., 5: 41-45.

Kabir F and T Haque, 2010. Study on production performance of ISA brown strain at Krishibid Firm ltd. Trishal, Mymensingh. Bd. Res. Pub. J., 3: 1039-1044.

Moreng R and JS Avens, 1985. Classification, nomenclature, and showing of poultry. Poultry Science and Production. Reston Publishing Co., Inc. Prentice-Hall Company. Reston, Virginia, 22090, pp.16-45.

Okedere DA, PQ Ademola and PM Asiwaju, 2020. Performance and cost-benefit analysis of ISA Brown layers on different management systems. Bull. Natl. Res. Cent. , 44: 1-7.

Oluyemi JA and FA Roberts, 1979. Poultry production in warm wet climates. Macmillan Press Ltd..

Rahman M, 2003. Growth of poultry industry in Bangladesh poverty alleviation and employment opportunity. In Proceedings of 3rd International Poultry Show and Seminar, Organized by World's Poultry Science Association-Bangladesh Branch, pp. 1-7.

Rahman S, IA Begum IA and MJ Alam, 2014. Livestock in Bangladesh: distribution, growth, performance and potential. LRRD, 26: 233-238.

Renema RA, FE Robinson, JJ Feddes, GM Fasenko and MJ Zuidhoft, 2001. Effects of light intensity from photostimulation in four strains of commercial egg layers: 2. Egg production parameters. Poult. Sci., 80: 1121-1131. 
Samad MA, 2013. Poultry Science and medicine, $2^{\text {nd }}$ edition, LEP publication, BAU campus, Mymensingh, Bangladesh.

Shaver-579 Brown product guide, cage production system, 2019.

Talukder S, T Islam, S Sarker S and MM Islam, 2010. Effects of environment on layer performance. J. Bangladesh Agril. Univ., 8: 253-258.

Commercial Layers Management Guide - Novogen-Brown, 2018. 